\title{
ANALISIS PENGARUH PEMAHAMAN KETENTUAN DAN PRESEPSI WAJIB PAJAK TENTANG PERATURAN PEMERINTAH NOMER 46 TAHUN 2013 TERHADAP KEPATUHAN DALAM MELAKSANAKAN KETENTUAN PADA WAJIB PAJAK PELAKU USAHA MIKRO KECIL DAN MENENGAH DI KOTA YOGYAKARTA
}

\author{
Yunitha Tri Kartika* \\ Andri Waskita Aji \\ Program Studi Akuntansi Fakultas Ekonomi \\ Universitas Sarjanawiyata Tamansiswa Yogyakarta \\ *nithamagitha@gmail.com
}

\begin{abstract}
This study aims to determine the effect of the provisions of the understanding and perception of actors taxpayer Micro, Small and Medium Enterprises of the Government Regulation No. 46 of 2013 on tax compliance in implementing the provisions of Government Regulation No. 46 of 2013 in the city of Yogyakarta. Sampling in this study using a convenience sampling and questionnaire survey method with the data collection. Respondents were sampled in this study are the individual taxpayers and corporate taxpayers in the city of Yogyakarta. Research data analysis using multiple linear regression with SPSS 17.0. Based on the results of the analysis conducted this study indicate that understanding the taxpayer on Government Regulation No. 46 of 2013 significantly influence taxpayer compliance in implementing the provisions of Government Regulation No. 46 of 2013. While variable taxpayer's perception of Government Regulation No. 46 of 2013 has no effect significantly on tax compliance in implementing the provisions of Government Regulation No. 46 of 2013.
\end{abstract}

Keywords: provision understanding and perception of the taxpayer on government regulation number 46 of 2013.

\section{PENDAHULUAN}

Pembangunan ekonomi diarahkan pada upaya mewujudkan perekonomian negara yang mandiri dan handal untuk meningkatkan kesejahteraan seluruh wilayah negara Indonesia secara adil dan merata, serta meningkatkan pendapatan bangsa Indonesia. Roda pemerintah dan pembangunan tidak mungkin dapat digerakkan tanpa dukungan dana terutama berasal dari pendapatan dalam negeri. Oleh karena itu pemerintah berusaha terus-menerus meningkatkan peranan sumber penerimaan negara, terutama penerimaan yang berasal dari non migas. Penerimaan dari non migas ini sebagian akan ditingkatkan melalui penerimaan dari sektor pajak (Suryadi dalam hapsari 2010).

Saat ini Pemerintah mulai melirik sektor swasta yang dipastikan memiliki potensi yang besar untuk pemasukan pajak, yaitu dari Usaha Mikro, Kecil, dan Menengah(UMKM). UMKM memliliki omset dan labanya memang lebih kecil dibandingkan dengan perusahaanperusahaan besar. Namun keberadaan usaha ini mampu memberikan sumbangsih yang berarti bagi pertumbuhan ekonomi. Namun demikian jika dilihat dari sisi kepatuhan wajib pajak UMKM ternyata masih banyak kekurangan. Banyak Wajib Pajak UMKM yang dengan sengaja tidak melaporkan dan membayar pajak, karena peraturan yang sulit untuk di mengerti. Bagi Wajib Pajak UMKM yang masih menggunakan perhitungan akuntansi sederhana belum mampu menyusun pembukuan secara rinci, hal ini juga menjadi faktor melemahnya tingkat kepatuhan Wajib Pajak khususnya UMKM. Hal ini merupakan tugas dari pemerintah untuk menyederhanakan peraturan yang ada.

Menanggapi hal itu maka baru-baru ini pemerintah merubah peraturan perpajakan atas 
penghasilan dari usaha Wajib Pajak yang memiliki peredaran bruto tertentu. Peraturan tersebut tertuang dalam Peraturan Pemerintah No. 46 Tahun 2013. Berdasarkan ketentuan ini,Wajib Pajak yang memenuhi kriteria dikenakan PPh Final dengan tarif 1\% dan dasar pengenaan pajaknya adalah peredaran bruto setiap bulan. Wajib Pajak yang dimaksud adalah Wajib Pajak orang pribadi atau Wajib Pajak badan bukan termasuk bentuk usaha tetap dan menerima penghasilan dari usaha, tidak termasuk penghasilan dari jasa sehubungan dengan pekerjaan bebas, dengan peredaran bruto tidak melebihi dari Rp 4.800.000.000 (empat miliar delapan ratus juta rupiah) dalam 1 Tahun Pajak.

Peraturan ini diadakan untuk mempermudah wajib pajak dalam membayar pajak. Selama ini, mereka harus mengkalkulasikan pendapatan dan beban mereka, sehingga pajak yang mereka bayar berdasarkan laba yang diperoleh dikali dengan tarif-tarif yang telah ditentukan. Peraturan ini mempermudah mereka sehingga para wajib pajak tidak perlu menghitung laba mereka, pajak yang harus dibayar langsung dikalikan 1\% dari omset saja. Namun masyarakat beranggapan bahwa pengenaan pajak terhadap UMKM sebesar $1 \%$ dari omset dinilai tidak adil bagi pengusaha UMKM. Omset belum tentu untung, jika ternyata mereka mengalami kerugian dan harus membayar pajak, hal ini akan memberatkan para wajib pajak UMKM. .

Rendahnya tingkat kepatuhan wajib pajak penyebabnya antara lain pengetahuan sebagian besar wajib pajak tentang pajak, serta persepsi wajib pajak tentang pajak dan petugas pajak masih rendah (Gardina dan Haryanto 2006). Sebagian besar wajib pajak memperoleh pengetahuan pajak dari petugas pajak, selain itu juga ada yang diperoleh dari radio, televisi, majalah pajak, surat kabar, internet, buku perpajakan, konsultan pajak, seminar pajak, dan ada pula yang diperoleh dari pelatihan pajak. Namun, frekuensi pelaksanaan kegiatan tersebut tidak sering dilakukan. Bahkan, pengetahuan tentang pajak belum secara komprehensif menyentuh dunia pendidikan. Oleh karena itu, pada tataran pendidikan mulai pendidikan dasar sampai pendidikan tinggi masih belum tersosialisasi pajak secara menyeluruh, kecuali mereka yang menempuh jurusan perpajakan. Kurangnya sosialisasi mungkin berdampak pada rendahnya kesadaran masyarakat yang pada akhirnya mungkin menyebabkan rendahnya tingkat kepatuhan wajib pajak.

\section{LANDASAN TEORI \\ Pengertian Pajak}

Pajak merupakan sumber utama penerimaan Negara yang digunakan untuk membiayai pengeluaran rutin maupun pembangunan agar tercapai kemakmuran dan kesejahteraan masyarakat. Hal tersebut tertuang dalam Anggaran Penerimaan dan Belanja Negara (APBN) dimana penerimaan pajak merupakan penerimaan dalam negeri yang terbesar (Muliari, 2011). Akan tetapi besarnya pajak penerimaan pajak masih belum diimbangi dengan peningkatan kepatuhan pajak masyarakat Indonesia. Fakta di Indonesia menunjukkan tingkat kepatuhan pajak masih rendah, ditandai belum optimalnya angka tax ratio (Jatmiko, 2006). Lambannya kenaikan tax ratio dikarenakan masih banyaknya kebocoran pajak terkait dengan belum baiknya pengelolaan potensi pajak yang masih banyak penyimpangan, seperti pungutan liar, suap, dan korupsi pajak sehingga menyebabkan persepsi negatif masyarakat terhadap pengelolaan pajak di negeri ini.

Kurangnya kesadaran masyarakat akan kewajibannya membayar pajak juga merupakan salah satu faktor utama rendahnya tax ratio. Meskipun demikian, tetap ada kendala dalam upaya meningkatkan tax ratio. Kendala tersebut adalah masalah kepatuhan Wajib Pajak(Jatmiko, 2006).

\section{Pemahaman Pajak}

Pemahaman adalah bentuk atau hasil proses belajar, kemaun diri dalam mengerti atau mengetahui dengan benar terhadap sesuatu. Menurut Mulyono (1998) dalam kamus besar bahasa Indonesia, paham berarti (a) mengerti benar (akan), tahu benar (akan), (b) pandai benar dan mengerti benar (terhadap sesuatu hal). Sedangkan pemahaman diartikan sebagai proses, perbuatan atau cara memahami. Jadi pemahaman merupakan suatu proses dari 
berjalannya pengetahuan seseorang. Menurut Hardiningsih (2011), pemahaman Wajib Pajak terhadap peraturan perpajakan adalah cara Wajib Pajak dalam memahami peraturan perpajakan yang telah ada. Wajib Pajak yang tidak paham akan peraturan perpajakan makan cenderung menjadi Wajib Pajak yang tidak taat.

\section{Persepsi}

Persepsi menurut Kamus Besar Indonesia adalah suatu tanggapan (penerimaan) langsung dari sesuatu atau merupakan proses seseorang mengenai beberapa hal yang dialami oleh setiap orang dalam memahami setiap informasi tentang lingkungan melalui panca indera. Apa yang ada dalam diri individu, pikiran, perasaan, pengalaman-pengalaman individu akan ikut aktif berpengaruh dalam proses persepsi. Persepsi bersifat subjektif karena melihat aspek spikologis yaitu proses kognitif, sehingga apa yang ada dalam pikiran individu akan ikut dalam menentukan persepsi individu. Menurut Gibson et al (1997) dalam Nisa' (2013), definisi persepsi adalah proses kognitif yang dipergunakan oleh individu untuk menafsirkan dan memahami dunia sekitarnya (terhadap obyek).

Berdasarkan pengertian di atas dapat disimpulkan bahwa pengertian persepsi merupakan suatu proses penginderaan, stimulus yang diterima oleh individu melalui alat indera yang kemudian diinterpretasikan sehingga individu dapat memahami dan mengerti tentang stimulus yang diterimanya tersebut. Proses menginterpretasikan stimulus ini biasanya dipengaruhi pula oleh pengalaman dan proses belajar individu. Persepsi atas PP Nomor 46 Tahun 2013 merupakan suatu proses dimana seseorang mengorganisasi, menginterpretasi, mengalami dan mengolah mengenai kesederhanaan, kemudahan, keadilan dan penghapusan sanksi administrasi yang tercantum didalam PP Nomor 46 Tahun 2007 sehingga diharapkan akan mampu meningkatkan kepatuhan WP.

\section{Peraturan Pemerintah No. 46 Tahun 2013}

Ketentuan Pajak Penghasilan yang diatur dalam Peraturan Pemerintah (PP) Nomor 46 Tahun 2013, merupakan kebijakan Pemerintah yang mengatur mengenai Pajak Penghasilan atas
Penghasilan dari Usaha yang Diterima atau Diperoleh Wajib Pajak yang Memiliki Peredaran Bruto Tertentu. Kebijakan Pemerintah dengan pemberlakuan PP ini didasari dengan maksud dan tujuan tertentu.

Maksud kebijakan Pemerintah terkait dengan pemberlakuan PP Nomor 46 Tahun 2013: 1) Untuk memberikan kemudahan dan penyederhanaan aturan perpajakan; 2) Mengedukasi masyarakat untuk tertib administrasi; 3)Mengedukasi masyarakat untuk transparansi; 4) Memberikan kesempatan masyarakat untuk berkontribusi dalam penyelenggaraan negara. Tujuan kebijakan Pemerintah terkait dengan pemberlakuan PP Nomor 46 Tahun 2013: 1) Kemudahan bagi masyarakat dalam melaksanakan kewajiban perpajakan; 2) Meningkatnya pengetahuan tentang manfaat perpajakan bagi masyarakat; 3)Terciptanya kondisi kontrol sosial dalam memenuhi kewajiban perpajakan.

Dalam hal ini atas penghasilan dari usaha yang diterima atau diperoleh Wajib Pajak yang memiliki peredaran bruto tertentu dikenai Pajak Penghasilan yang bersifat final. Berikut adalah Wajib Pajak yang dimaksud, antara lain: a. Wajib Pajak orang pribadi atau Wajib Pajak badan tidak termasuk bentuk usaha tetap; dan $b$. Menerima penghasilan dari usaha, tidak termasuk penghasilan dari jasa sehubungan dengan pekerjaan bebas, dengan peredaran bruto tidak melebihi Rp 4.800.000.000,00 (empat miliar delapan ratus juta rupiah) dalam 1 (satu) Tahun Pajak.

Tidak termasuk Wajib Pajak orang pribadi adalah Wajib Pajak orang pribadi yang melakukan kegiatan usaha perdagangan dan/atau jasa yang dalam usahanya: a. menggunakan sarana atau prasarana yang dapat dibongkar pasang, baik yang menetap maupun tidak menetap; dan b. menggunakan sebagian atau seluruh tempat untuk kepentingan umum yang tidak diperuntukkan bagi tempat usaha atau berjualan.

Dalam PP No. 46 menjelaskan tidak semua Wajib Pajak Badan yag memiliki usaha dan memperoleh penghasilan bruto tertentu terkena tarif 1\% ini. Berikut adalah Wajib Pajak Badan yang tidak termasuk dalam kriteria, antara lain: a. Wajib Pajak badan yang belum 
beroperasi secara komersial; atau b. Wajib Pajak badan yang dalam jangka waktu 1 (satu) tahun setelah beroperasi secara komersial memperoleh peredaran bruto melebihi $\mathrm{Rp} 4.800 .000 .000,00$ (empat miliar delapan ratus juta rupiah).

\section{Kepatuhan Wajib Pajak}

Menurut Kamus Besar Bahasa Indonesia, kepatuhan berarti tunduk atau patuh pada ajarana atau aturan. Menurut Rustyaningsih (2011) dalam Nisa' (2013) kepatuhan perpajakan dapat diartikan sebagai suatu keadaan yang mana Wajib Pajak patuh dan mempunyai kesadaran dalam memenuhi kewajiban perpajakan.

Kepatuhan Wajib Pajak merupakan pemenuhan kewajiban perpajakan yang dilakukan oleh pembayar pajak dalam rangka memberikan kontribusi bagi pembangunan dewasa ini yang diharapkan di dalam pemenuhannya diberikan secara sukarela. Kepatuhan Wajib Pajak menjadi aspek penting mengingat sistem perpajakan Indonesia menganut Self Asessment System, di mana dalam prosesnya secara mutlak memberikan kepercayaan kepada Wajib Pajak untuk menghitung., membayar dan melapor kewajiban perpajakannya.

\section{HIPOTESIS}

H1: Pemahaman wajib pajak berpengaruh positif signifikan terhadap tingkat kepatuhan wajib pajak

H2: Persepsi Wajib Pajak berpengaruh positif signifikan terhadap tingkat kepatuhan Wajib Pajak

H3: Pemahaman ketentuan dan persepsi Wajib Pajak berpengaruh positif signifikan terhadap tingkatkepatuhan Wajib Pajak

\section{METODOLOGI PENELITIAN}

Penelitian ini dilakukan di Yogyakarta dalam kurun waktu tahun 2015. Populasi dalam penelitian ini adalah Wajib Pajak Orang Pribadi dan Wajib Pajak Badan yang berada di Kota Yogyakarta. Tidak semua Wajib Pajak dalam populasi akan dijadikan obyek penelitian karena jumlahnya terlalu banyak. Guna efisiensi waktu dan biaya maka dilakukan pengambilan sampel. Pengambilan sampel dilakukan dengan metode purposive sampling. Purposive sampling yaitu pengambilan sampel secara sengaja sesuai dengan persyaratan sampel yang diperlukan.

Penelitian ini adalah penelitian kuantitatif. Dengan cara ini maka suatu fenomena dapat dianalisis untuk kemudian dijelaskan hubungan diantara variabel-variabel yang terlibat di dalamnya. Karakteristik dari temuan hasil penelitian dengan pendekatan ini lebih bersifat perumusan suatu bentuk hubungan yang umum, ringkas untuk dijelaskan, dan dapat digeneralisasikan. Penelitian ini mengukur tentang analisis pengaruh pemahaman ketentuan dan presepsi wajib pajak tentang Peraturan Pemerintah Nomer 46 Tahun 2013 terhadap kepatuhan dalam melaksanakan ketentuan pada wajib pajak pelaku usaha mikro, kecil, dan menengah di Kota Yogyakarta

Dalam penelitian ini terdapat dua variabel, yaitu variabel dependen dan variabel independen. Variabel dependen adalah variabel yang dijelaskan atau dipengaruhi oleh variabel independen. Variabel dependen yang digunakan adalah kepatuhan Wajib Pajak.Variabel independen adalah variabel yang menjelaskan atau mempengaruhi variabel yang lain. Penelitian ini menggunakan variabel independen yang terdiri dari pemahaman dan persepsi Wajib Pajak. Untuk lebih jelasnya akan digambarkan dalam kerangka pikir.

\section{Kerangka Pemikiran}

$$
\begin{aligned}
& \text { X1: Pemahaman Ketentuan tentang } \\
& \quad \text { PP No. } 46 \text { Tahun } 2013 \\
& \text { X2: Persepsi tentang PP No. } 46 \text { Tahun } \\
& 2013
\end{aligned}
$$
Y: Kepatuhan Wajib Pajak UMKM 


\section{HASIL DAN PEMBAHASAN}

Berdasarkan analisis yang telah dilakukan secara simultan bahwa variabel variabel yaitu pemahaman wajib pajak berpengaruh positif signifikan dan persepsi wajib pajak tidak berpengaruh signifikan. hal ini dapat dilihat dari hasil uji regresi linier berganda.

\section{Hasil Uji Regresi Linear Berganda}

\begin{tabular}{|c|c|c|c|c|c|c|}
\hline \multicolumn{7}{|c|}{ Coefficients $^{\mathrm{a}}$} \\
\hline & \multirow[t]{2}{*}{ Model } & \multicolumn{2}{|c|}{ Unstandardized Coefficients } & \multirow{2}{*}{$\begin{array}{c}\text { Standardized } \\
\text { Coefficients }\end{array}$} & \multirow[t]{2}{*}{$\mathrm{t}$} & \multirow{2}{*}{ Sig. } \\
\hline & & B & Std. Error & & & \\
\hline \multirow[t]{3}{*}{1} & (Constant) & 17.965 & 4.575 & & 3.927 & .000 \\
\hline & pemahaman & .422 & .098 & .441 & 4.326 & .000 \\
\hline & persepsi & .055 & .093 & .061 & .594 & .554 \\
\hline
\end{tabular}

Berdasarkan tabel persamaan regresi dari penelitian ini adalah sebagai berikut:

$$
\mathrm{Y}=17.965+0.422+0.055+\mathrm{e}
$$

Dimana:

$\mathrm{Y} \quad=$ Kepatuhan wajip pajak

$\mathrm{X} 1=$ Pemahaman Wajib Pajak

$\mathrm{X} 2=$ Persepsi Wajib Pajak

Konstanta sebesar 17.965 menyatakan bahwa pemahamn tentang PP No 46 tahun 2013 dan persepsi tentang PP No. 46 tahun 2013 bernilai 0 (nol), maka besarnya tingkat kepatuhan wajib pajak sebesar 17.965. Pemahaman tentang PP No. 46 tahun 2013 (X1) mempunyai nilai koefisien 0.422 menyatakan bahwa setiap peningkatan $1 \%$ pemahaman tentang PP No. 46 tahun 2013 (dengan asumsi nilai koefisien variabel lain tetap dan tidak berubah) maka akan meningkatkan kepatuhan wajib pajak sebesar 0.422 . Namun sebaliknya jika X1 mengalami penurunan sebesar $1 \%$, maka kepatuhan wajib pajak diprediksi mengalami penurunan sebesar 0.422 .

Persepsi tentang PP No. 46 tahun 2013 (X2) mempunyai nilai koefisien sebesar 0.055 artinya bahwa setiap peningkatan $1 \%$ persepsi tentang PP No. 46 tahun 2013 (dengan asumsi nilai koefisien variabel lain tetap dan tidak berubah) maka akan meningkatkan kepatuhan wajib pajak sebesar 0.055. Namun sebaliknya jika X2 mengalami penurunan sebesar $1 \%$, maka kepatuhan wajib pajak diprediksi mengalami penurunan sebesar 0.055 .

Hasil uji hipotesis secara individu menunjukkan bahwa nilai $\mathrm{t}$ hitung untuk variabel pemahaman tentang PP No. 46 tahun 2013 (X1) terhadap kepatuhan dalam melaksanakan ketentuan pada pelaku UMKM (Y) sebesar 4.326, berarti t hitung > t tabel (4.326 > 2.33), memiliki tingkat signifikansi 0.000 karena tingkat signifikansi lebih kecil dari 0.05 hal ini menunjukkan bahwa variabel pemahaman tentang PP No. 46 tahun 2013 berpengaruh positifsignifikan terhadap kepatuhan dalam melaksanakan ketentuan pada pelaku UMKM. Hasil penelitian ini mendukung hasil penelitian yang dilakukan Adiasa (2013) dan Rajif (2011), namun berbeda dengan hasil penelitian Pranadata (2014).

Hasil pengujian variabel persepsi tentang PP No. 46 tahun 2013 (X2) terhadap kepatuhan dalam melaksanakan ketentuan pada pelaku UMKM (Y) sebesar 0,594, berarti t hitung < t tabel $(0,594<2,33)$, memiliki tingkat signifikansi 0.544 karena tingkat signifikansi lebih besar dari 0.05 hal ini menunjukkan bahwa variabel tentang PP No. 46 tahun 2013 tidak berpengaruh positif terhadap kepatuhan dalam melaksanakan ketentuan pada pelaku UMKM. Hasil ini mendukung penelitian yang dilakukan Asih (2009), namun berbeda dengan hasil penelitian Nashrudin (2014). Hal tersebut menunjukkan persepsi tentang PP No. 46 tahun 
2013 tidak berpengaruh terhadap kepatuhan dalam melaksanakan ketentuan pada pelaku UMKM, karena kemungkinan wajib pajak mempunyai anggapan bahwa membayar pajak itu adalah suatu kewajiban.

\section{PENUTUP \\ Kesimpulan}

Penelitian ini bertujuan mengetahui pengaruh pemahaman dan persepsi Wajib Pajak pelaku Usaha Mikro, Kecil, dan Menengah tentang Peraturan Pemerintah Nomor 46 tahun 2013 terhadap kepatuhan wajib pajak dalam melaksanakan ketentuan Peraturan Pemerintah Nomor 46 tahun 2013. Berdasarkan penelitian yang dilakukan pada pelaku UMKM di Kota Yogyakarta maka dapat diambil kesimpulan sebagai berikut: 1) Pemahaman wajib pajak tentang Peraturan Pemerintah Nomor 46 tahun 2013 berpengaruh signifikan terhadap kepatuhan wajib pajak dalam melaksanakan ketentuan Peraturan Pemerintah Nomor 46 tahun 2013; 2) Persepsi wajib pajak tentang Peraturan Pemerintah Nomor46 tahun 2013 tidak berpengaruh signifikan terhadap kepatuhan wajib pajak dalam melaksanakan ketentuan Peraturan Pemerintah Nomor 46 tahun 2013.; 3) Pemahaman dan persepsi wajib pajak tentang Peraturan Pemerintah Nomor 46 tahun 2013 secara bersama-sama berpengaruh signifikan terhadap kepatuhan wajib pajak dalam melaksanakan ketentuan Peraturan Pemerintah Nomor 46 tahun 2013.

\section{DAFTAR PUSTAKA}

Adiasa, Nirawan. 2013. "Pengaruh Peahaman Peraturan Pajak Terhadap Kepatuhan Wajib Pajak dengan Moderating Peferensi Risiko". Jurnal. Program Studi Akuntansi Fakultas Ekonomi Universitas Negeri Semarang.

Agustina B, Etha yuny. 2014. "Penerapan PP No. 46 Tahun 2013. Skripsi. Program Studi Akuntansi Fakultas Ekonomi dan Bisnis Universitas Brawijaya Malang.

Arikunto, Suharsimi. 2009. Dasar-Dasar Evaluasi Pendidikan (edisi revisi). Cetakan IX; Jakarta; Bumi Aksara.
Asih, Devi Tri. 2009. "Pengaruh Pengetahuan

Tentang Pajak, Persepsi Tentang Petugas Pajak Dan Penerapan Sistem Administrasi Perpajakan Modern Terhadap Kepatuhan Wajib Pajak". Skripsi. Program Studi Akuntansi Sekolah Tinggi Ilmu Ekonomi PERBANAS Surabaya.

Chaniago Amran Ys. 2002. Kamus Lengkap Bahasa Indonesia. Cetakan V; Bandung; Pustaka Setia.

Ghozali, Imam. 2007. Analisis Multivariate dengan program SPSS. Semarang; Badan Penerbit Universitas Diponegoro.

Indrianto, Nur Bambang. 1999. Metode Penelitian Bisnis.

Mardiasmo. 2011. Perpajakan, edisi revisi. Yogyakarta; Andi.

Nashrudin, Ahsan, Bashori, dan Elia Mustikasari. 2014. " Pengaruh Persepsi Atas PP Nomor 46 Tahun 2013 Terhadap Kepatuhan Sukarela Wajib Pajak Yang Memiliki Peredaran Bruto Tertentu Pada Kantor Pelayanan Pajak Pratama Surabaya Rungkut”. Skripsi. Universitas Airlangga.

Pedoman Penulisan Skripsi Fakultas Ekonomi Universitas Sarjanawiyata Tamansiswa 2014.

Peraturan Pemerintah Republik Indonesia nomor 46 Tahun 2013 tentang Pajak Penghasilan Atas Penghasilan Dari Usaha Yang Diterima Atau Diperoleh Wajib Pajak Yang Memiliki Peredaran Bruto Tertentu.

Pranadata, I Gede Putu. 2014. "Pengaruh Pemahaman Wajib Pajak, Kualitas Pelayanan Perpajakan, Dan Pelaksanaan Sanksi Pajak, Terhadap Kepatuhan Wajib Pajak Orang Pribadi Pada Kpp Pratama Batu”. Jurnal Skripsi. Program Studi Akuntansi Fakultas Ekonomi dan Bisnis Universitas Brawijaya Malang.

Rajif, Mohamad. 2011. "Pengaruh Pemahaman, Kualitas Pelayanan, dan Ketegasan 
Sanksi Perpajakan Terhadap Kepatuhan Pajak Pengusaha UKM di Daerah Cirebon". Skripsi. Program Studi Akuntansi Fakultas Ekonomi Universitas Gunadarma.

Sadiman, Arif Sukadi. 2011. Beberapa Aspek Pengembangan Sumber Belajar. Cetakan 1; Jakarta; Mediyatama Sarana Perkasa.

Santoso, Singgih. 2000. Buku Latihan SPSS Statistik Parametrik. Jakarta; Elek Media Komputindo.

Setyaningsih, Titik dan Ridwan, Ahmad. 2014. "Persepsi Wajib Pajak Umkm Terhadap Kecenderungan Negosiasi Kewajiban Membayar Pajak Terkait Peraturan Pemerintan Nomor 46 Tahun 2013”. Jurnal. Universitas Sebelas Maret Surakarta. 